$\begin{array}{r}\text { Contents lists available at BIOSFER } \\ \text { BIOSFER: JURNAL TADRIS BIOLOGI } \\ \text { p-ISSN: 2086-5945 (print), e-ISSN: 2580-4960 (online), DOI 10.24042/biosphere } \\ \text { http://ejournal.radenintan.ac.id/index.php/biosfer/index } \\ \hline \hline\end{array}$

\title{
The Relationship between Self Efficacy and Environmental Literacy in Pollution and Environmental Changes Learning Material
}

\author{
Rani Rosdiana1*; Djohar Maknun²; Evi Roviati ${ }^{3}$ \\ 1,2,3Biology Education Department, IAIN Syekh Nurjati Cirebon, West Java, Indonesia
}

\section{ARTICLE INFO}

\section{Article History}

Received : 01-02-2020

Accepted : 28-08-2020

Published : 27-12-2020

Keywords:

Self-Efficacy;

Environmental Literacy;

Pollution and Environmental Change

*Correspondence Address: rosdianadzulkarnaen19@ymail.com

ABSTRACT

The purposes of this research were examining students' self-efficacy in pollution and environmental change learning; assessing the level of students' environmental literacy in pollution and environmental change learning; and analyzing the relationship between self-efficacy and environmental literacy in pollution and environmental change learning. The sample was determined using the purposive sampling technique. This research was a descriptive quantitative research with a single paradigm correlation design. The data collection techniques used were tests, questionnaires, and documentation. The results showed that students' self-efficacy was in the strong category with an average score of 73; students' environmental literacy was in the moderate category with an average score of 60.2 . The correlational value between selfefficacy and environmental literacy was 0.572 in the moderate category. The correlational value of the two variables was in a positive direction. Good self-efficacy tends to produce good environmental literacy.
\end{abstract}

\section{Hubungan Self Efficacy Dengan Literasi Lingkungan Dalam Pembelajaran Pencemaran Dan Perubahan Lingkungan}

\begin{abstract}
Abstrak: Tujuan penelitian ini mengkaji self efficacy siswa dalam pembelajaran pencemaran dan perubahan lingkungan; mengkaji tingkat literasi lingkungan siswa dalam pembelajaran pencemaran dan perubahan lingkungan; menganalisis hubungan self efficacy dengan literasi lingkungan dalam pembelajaran pencemaran dan perubahan lingkungan. Penentuan sampel dilakukan dengan teknik purposive sampling atau sampel bertujuan. Penelitian yang dilakukan merupakan penelitian secara kuantitatif deskripsi. Sementara design penelitian yang digunakan dalam penelitian adalah korelasi dengan paradigma sederhana. Teknik pengumpulan data dengan menggunakan tes, angket, dan dokumentasi. Hasil penelitian menunjukkan siswa mempunyai self efficacy pada kategori kuat dengan rata-rata 73; memiliki literasi lingkungan yang berkategori cukup dengan rata-rata 60,2 dan korelasi antara self efficacy dengan literasi sebesar 0,572 yang termasuk pada
\end{abstract}


kategori cukup, nilai korelasi kedua variabel tersebut bertanda positif. Self efficacy (keyakinan diri) yang baik mempunyai kecenderungan untuk menghasilkan literasi lingkungan yang baik juga.

\section{INTRODUCTION}

Education can develop human resources' potential (HR) through learning activities (Kristiawan et al., 2017; Kusmanto, 2014; Sudarsana, 2016). Human tries to develop their personality based on the society and culture values (Hani'ah et al., 2017; Trianingsih, 2017). Development is expected for a person or a group to mature or reach a higher level of life or livelihood in a mental sense(Erwanto, 2019; Qomara, 2015; Shawmi, 2015). Human beings' objective is closely related to the learning process (Imelda, 2017; Rahmi, 2017).

Effective learning is characterized by students' learning process (Bintari \& Martuti, 2012; Emda, 2017; Pane \& Dasopang, 2017; Winataputra et al., 2014). A person is said to have experienced a learning process if he/she has changed, from not knowing to know (Falahudin, 2014; Nuriadin \& Perbowo, 2013; Syarifuddin, 2011). One of the environmental learning is biology.

Biology learning also plays a role in developing logical thinking and understanding of life symptoms (BARIAH, 2013; Hidayati, 2016). Students are invited to love and appreciate nature. Biology also discusses the types, causes, consequences, and countermeasures of environmental change and pollution (Astuti, 2017).

People's ignorance of the environment will damage natural resources, which will cause natural disasters(Husin, 2017; Siddiq et al., 2020). The size of the human population also affects environmental damage. The lack of environmental literacy increases the level of environmental damage (Siddiq et al., 2020).

The literacy increase cannot be separated from the attitudes and beliefs. Self-efficacy is one part of the affective domain assessment (HASANAH et al., 2019) because it makes someone believes that he/she can control the situation and produce positive results (Sitompul, 2018). Students with low self-esteem feel inadequate, inferior, ashamed, afraid, and closed off.

Previous research found that students with low self-efficacy are less accustomed to thinking during the learning process (Indrawati \& Wardono, 2019; Rustaman, 2011). It also affects students' environmental care attitudes, where they cannot apply their good attitudes to the environment. Some students are littering and lazing around during cleaning duty. The previous research discussed the relationship between self-efficacy and problem-solving abilities (Jatisunda, 2017) and the relationship between self-efficacy and problem-solving (Handayani, 2013). Also, environmental literacy has been previously studied by Nasution (Nasution, 2016) by analyzing environmental literacy. Hekmah (Hekmah et al., 2019) focused her research on improving environmental literacy through web worksheets. Azizah researched pollution and environmental change learning materials similar to Phe eXelearning Internet media to improve learning outcomes (Azizah et al., 2017). Lastly, Supriyatin applied AJEL to environmental change learning (Supriyatin et al., 2016).

This research's novelty lies in examining the relationship between selfefficacy and environmental literacy in pollution and environmental change learning. Thus, the purposes of this research were examining students' self-efficacy in pollution and environmental change learning; assessing the level of students' environmental literacy in pollution and environmental change learning; and analyzing the relationship between self- 
efficacy and environmental literacy in pollution and environmental change learning.

\section{METHOD}

This research employed descriptivequantitative research with a correlation research design. This research was conducted on the tenth-grade students of SMAN 1 Tanjung in the 2019/2020 academic year. SMAN 1 Tanjung is located at Tanjung District, Brebes Regency. The populations of this research were all tenthgrade students of SMAN 1 Tanjung. The samples were determined using the purposive sampling technique. The samples consisted of two classes with thirty-five students each. The research framework can be seen in figure 1.

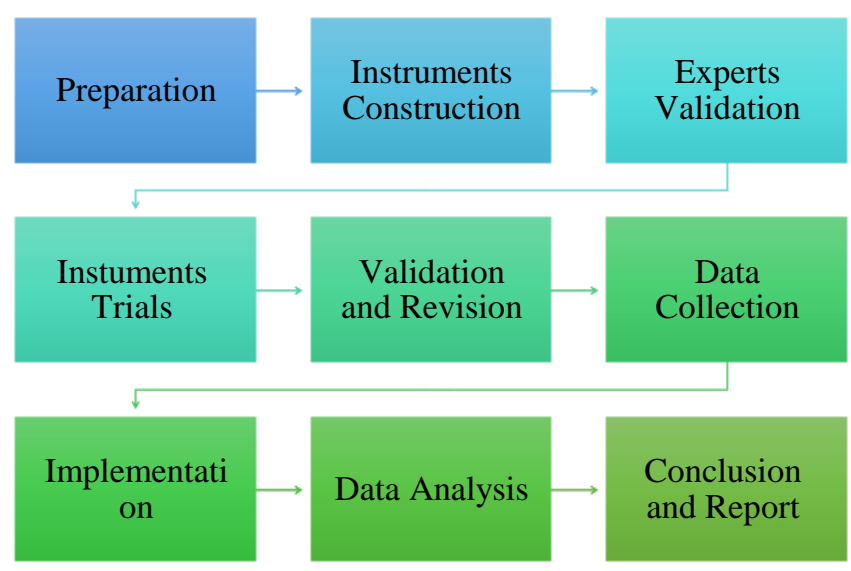

Picture 1.Research Framework

\section{RESULTS AND DISCUSSION}

The analysis results show that there were sixteen students with excellent selfefficacy (23\%), and there were no students with poor self-efficacy $(0 \%)$.

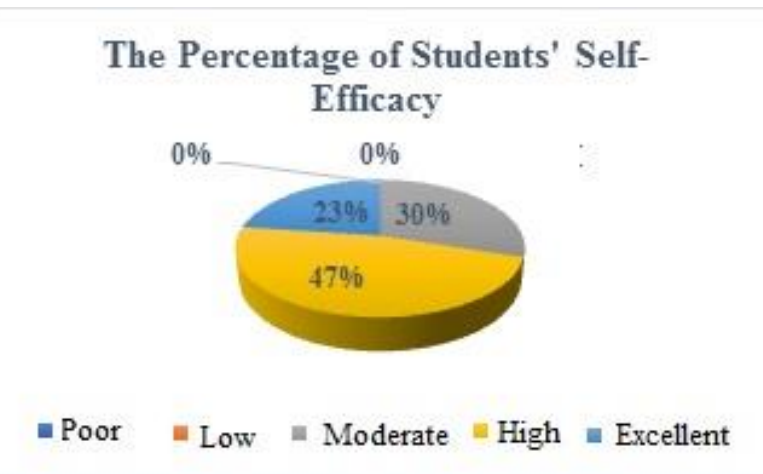

Figure 2. The Percentage of Students' SelfEfficacy Categories

Figure 2 shows that the students were in the high or excellent self-efficacy categories. The results show that most students were confident in determining and carrying out learning activities to achieve predetermined goals.

Students with high or strong selfefficacy tend to develop their interest in an activity, develop goals, and commit to achieving these goals. They also increase their efforts to prevent potential failures. Students with high self-efficacy already have confidence in their ability to carry out their duties properly. They have self-confidence in facing difficult tasks and feel confident in their ability to solve all the problems they face. They can analyze their actions and increase their efforts to achieve their learning goals.

The factors that cause increased selfefficacy are culture, gender, the nature of the task at hand, external intensity, status or role of individuals in their environment, and information about their abilities. The researchers found one of the self-efficacy factors, namely the nature of the task faced by students. The assignment or question given to students was at a medium difficulty. Thus, the students could solve the questions well. Conversely, if individuals face easy and simple tasks, they will over-assess their ability because they believe they can complete the task well (Pudjiastuti, 2012).

The results are in line with previous research conducted by Ariaji and Harahap 
(Ariaji et al., 2018; D. Harahap, 2008) that a positive and significant relationship indicates students with high self-efficacy have higher learning achievements. Students' self-efficacy greatly determines the level of improvement and achievement because they can plan actions, display new behavior, respond actively and creatively, provide solutions, or solve problems. Students with high self-efficacy can survive difficult situations, challenges, and tasks. Students with strong self-efficacy can achieve high achievements.

Bandura (HASANAH et al., 2019) explains that people with high self-efficacy can approach difficult tasks as challenges that must be mastered, not as threats to be avoided. People with high self-efficacy believe that they can do something to change the events around them. On the other hand, someone with low self-efficacy considers himself cannot do something. Selfefficacy affects individuals include choice behavior, efforts, endurance, thought patterns, and emotional reactions. Aini (Aini et al., 2015) states that self-efficacy has many similarities with mastery, motivation, and intrinsic motivation. Students with high self-efficacy face tasks with great desire.

Students' self-efficacy is different in many aspects, sich as the magnitude (level of task difficulty), strength (strength of belief), and generality. The detail of students' selfefficacy in each aspect is shown in the following histogram:

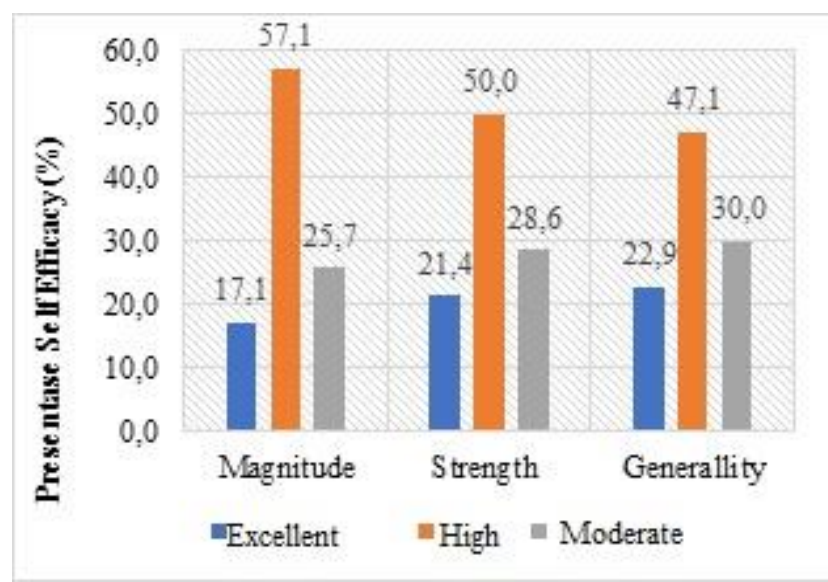

Figure 2. The Percentage of Students' SelfEfficacy Aspects Categories

Based on the analysis results, the strongest aspect was the magnitude with a percentage of $57.1 \% \quad$ (40 students). It indicates that the students perceive that they can complete difficult tasks. They do not give up easily when they have difficulty, and they can find solutions to the difficulties they face. Besides, students with high or strong self-efficacy in the magnitude aspect tend to choose activities that they can do well and maximize their learning efforts.

Fifty percent of students (35 students) possess high self-efficacy in the strength aspect. They are not easily influenced by the environment that affects the strength of their belief in their abilities. They also have resilience and tenacity in learning. At the same time, students with weak strength can be easily influenced by their environment, so that they are not sure of the effort they are making and will tend to be lazy in studying.

Students with high or strong selfefficacy in the generality aspect can carry out learning activities on other materials. They not only focus on one material and individual beliefs to complete certain tasks completely and well. On the other hand, students with low self-efficacy in the generality aspect can only display their learning activities limited to a certain learning activity series.

Based on the analysis, the highest aspect of self-efficacy of the tenth-grade students of SMAN 1 Tanjung was the magnitude aspect. The results are in line with previous studies conducted by Sunaryo (Sunaryo, 2017) that the students' magnitude aspect was in the moderate and positive level. Students will make enough efforts to do tasks that are deemed feasible and avoid situations and behaviors beyond their limits. Students at MTs N 2 Ciamis have moderate tenacity and persistence when facing challenging and difficult assignments. 
The principle is that they will not easily give up or avoid the assignment given by the teacher. They will give up if they have tried earnestly, but the task cannot be completed. The degree of anxiety they experience while maintaining tasks that cover their lives is also moderate. It means that the students are not too anxious and not too optimistic by remaining calm.

Measuring environmental literacy is needed to determine the extent of a person's environmental literacy skills so that followup actions can be done to improve. Prasetyo (PRASETYO, 2017) states that environmental literacy consists of four parts, namely students' knowledge of the environment, cognitive skills, attitudes, and behavior towards the environment. The literacy section is also a component of assessing a person's environmental literacy skills. The results of students' environmental literacy can be seen in the following diagram.

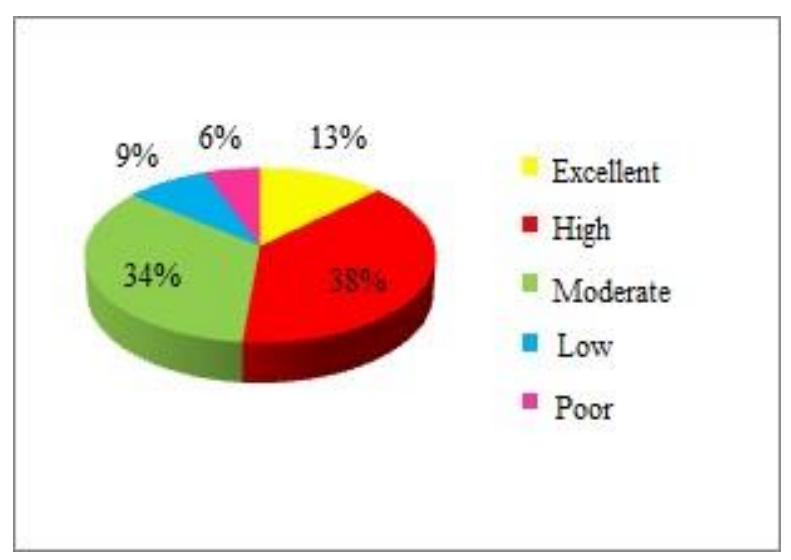

Figure 3. The Percentage of Students' Environmental Literacy

Based on Figure 3, it can be seen that nine students had excellent environmental literacy (12.9\%), twenty-seven students had high environmental literacy (38.6\%), twenty-four students had moderate environmental literacy (34.3\%), six students had low environmental literacy (8.6\%), and four students had poor environmental literacy (5.7\%).

The average percentage of students' environmental literacy was 60.2. It indicated that the students had moderate environmental literacy category. The moderate category was obtained because the intervals of the students' environmental literacy scores were between 40-60. The students could find environmental solutions around them, behave, and act according to their knowledge.

This is in line with Lailatussaadah's (Lailatussaadah et al., 2020) research that a person is considered having environmental knowledge if he has knowledge and attitudes about the environment and related problems to the environment. Through the skills acquired, he can help minimize or solve environmental problems and contribute to society. Behavior and attitudes towards environmental awareness are the responsibility of each individual, which is generally influenced by the knowledge factor. People with a high level of environmental knowledge will influence their environmental attitude and behavior.

Astuti (Fulu et al., 2017) found that environmental literacy is not high because students do not understand the learning material. The teacher teaches the material in terms of theories and concepts. The content of the lesson plans and what is delivered by the teacher should meet the environmental literacy component. Also, the school has not integrated environmental learning through the curriculum. 


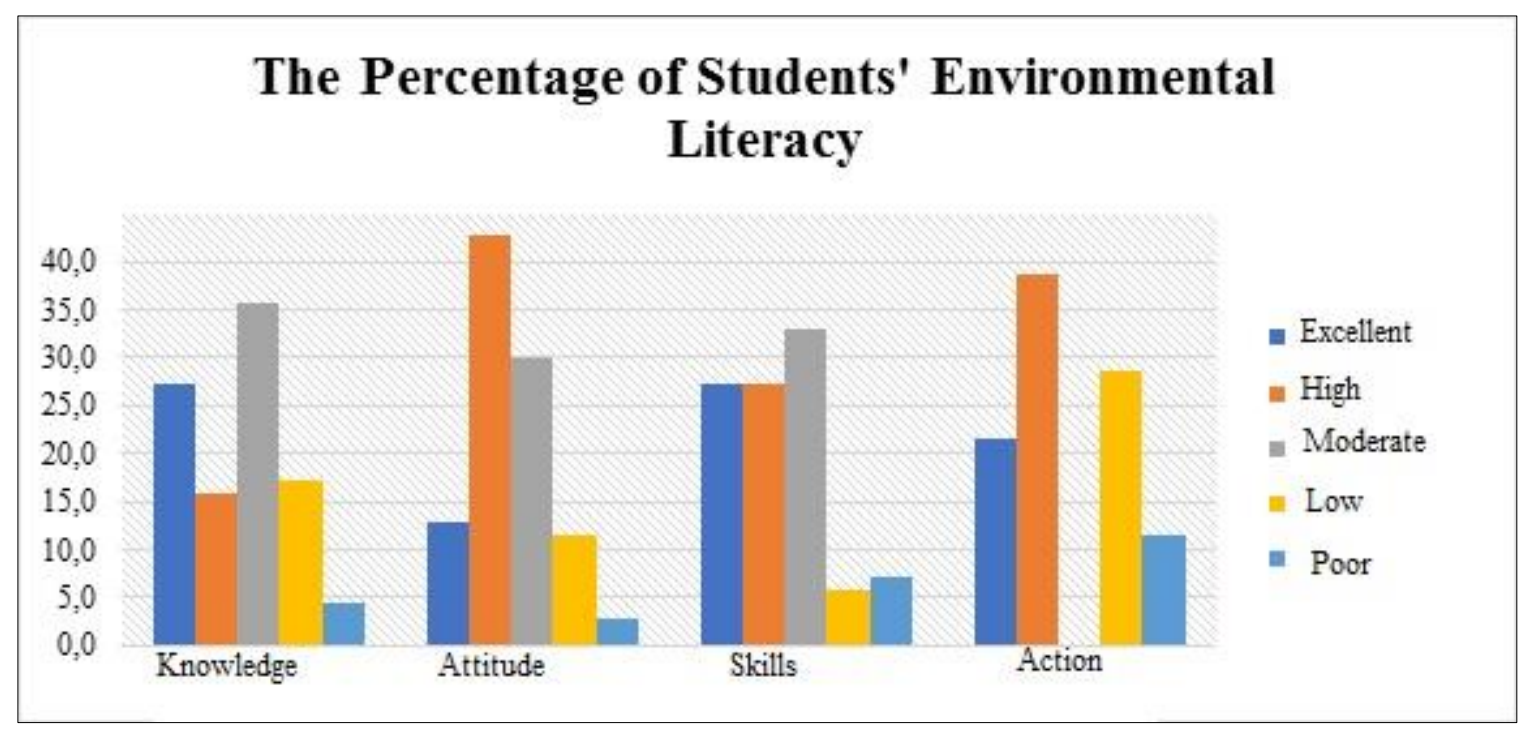

Figure 4. The Percentage of Student Environmental Literacy Indicators

Based on the analysis, it can be said that the environmental literacy of the tenthgrade students of SMAN 1 Tanjung was in the moderate category. The aspects were interrelated. The students' environmental knowledge was in line with their attitudes, skills, and behavior or actions. Taff (Taff et al., 2010)s states that environmental knowledge influences attitudes, which in turn increases behavioral intention. Furthermore, other researchers believe that the motivation to care for the environment, as a literal manifestation of society, results from the interaction between knowledge, attitudes, and concern for the environment. Besides the four factors that can increase environmental literacy (knowledge, attitudes, skills, and behavior), increasing literacy is also determined by the methods, models, or programs (Afrianda et al., 2019; Culture, nd; Komariah et al., 2020).

The students had different environmental literacy indicators. The students' environmental literacy for each indicator is shown in the histogram in Figure 4. Based on Figure 4, the overall results of environmental literacy indicators were in the high category, with an average percentage of 31.1. The Knowledge aspect of environmental literacy was in the moderate category, namely 35.7. This result showed that the students could understand environmental concepts, issues, and problems.

The Attitude aspect of environmental literacy was in the high category, namely 42.9. This result was in line with the results of the Knowledge aspect. Since the knowledge aspect is related to the attitude aspect, a high Knowledge aspect will produce a good attitude. Students' moderate knowledge of environmental literacy will encourage them to act according to their understanding of the knowledge. Pujianti (Pujianti et al., 2018) states a correlation between knowledge and attitudes aspects in environmental literacy.

The students' Skills aspect of environmental literacy was in the moderate category. They can find information about the surrounding environment and skillfully identify and find solutions to existing environmental problems. The thinking skills will encourage students to take positive action. Furthermore, environmental literacy skills will make them more productive by planning, implementing, and evaluating their actions.

Based on the results of the correlational test, the significant value is 0.000 . Since the significant value was less 
than 0.05 , then $\mathrm{H}_{\mathrm{o}}$ was rejected, and $\mathrm{H}_{\mathrm{a}}$ was accepted. The results indicated a positive relationship between self-efficacy and students' environmental literacy skills in learning pollution and environmental change. The relationship between selfefficacy and students' environmental literacy can be seen in the following table:

Table 1. The Correlational Value between Self-Efficacy and Environmental Literacy

\begin{tabular}{ccc}
\hline $\mathbf{N}$ & $\begin{array}{c}\text { Self-Efficacy } \\
\text { (X) }\end{array}$ & $\begin{array}{c}\text { Environmental } \\
\text { Literacy (Y) }\end{array}$ \\
\hline 70 & 73 & 60.2 \\
\hline
\end{tabular}

Based on the results of data analysis, it was found that the overall results of the tenth-grade students' self-efficacy at SMPA 1 Tanjung was in an excellent category with moderate environmental literacy. The results of the correlation test between selfefficacy and environmental literacy were 0.572 which was included in the sufficient category with a significant value of 0.000 . The correlation value of the two variables was positive. The correlation value was between 0.400 to 0.699 which means that there was a positive relationship between self-efficacy and students' environmental literacy in pollution and environmental change learning.

The results showed that the higher the student's self-efficacy, the higher their environmental literacy in environmental change and pollution learning. The students can complete assignments well, carry out learning activities well, and improve their academic achievement. Conversely, the lower the student's self-efficacy, the lower their environmental literacy in environmental change and pollution learning.

These results are in line with research conducted by Harahap (EK Harahap et al., 2018) that self-efficacy has a positive relationship with environmental concern (caring for the environment) in the community along the Deli River. This can be seen from the correlation value ( $\mathrm{r}$ ), which is 0.878 with $p=0.000$. It means that the higher the subject's self-efficacy, the higher their environmental concern, and vice versa.

\section{CONCLUSIONS AND SUGGESTIONS}

Based on the study results, it is concluded that students' self-efficacy was in the excellent category. Also, their environmental literacy was in the moderate category. The correlation between students' self-efficacy and their environmental literacy was in the moderate category positively correlational. Good self-efficacy tends to produce good environmental literacy. It is suggested to use this research as a reference for further research.

\section{REFERENCE}

Afrianda, R., Yolida, B., \& Marpaung, RR (2019). The Influence of the Adiwiyata Program on Environmental Literacy and Environmental Care Attitudes. Journal of Biotechnology: A Vehicle for Scientific Expression, 7 (1), 32-42.

Aini, SN, Es, DP, \& Saptono, A. (2015). The Influence of Family Environment and Self-Efficacy on Entrepreneurial Motivation in Students of the Faculty of Economics, State University of Jakarta. Journal of Economics and Business Education (Jpeb), 3 (1), 22-50.

Ariaji, R., Harahap, D., \& Tuah, S. (2018). Application of Computer Assisted Inquiry Model to Chemistry Learning Interest in Senior High School 4 Padangsidimpuan. Exact: Journal of Mathematical Research and Learning, 3 (1), 1-8.

Astuti, P. (2017). Increasing Students' Motivation and Creative Thinking 
Ability on Environmental Pollution Material Through Photonovela Media. Educational Reflections: Educational Scientific Journal, 8 (1).

Azizah, S., Khuzaemah, E., \& Lesmanawati, IR (2017). Use of Internet Exe-Learning Media Based on Problems in Environmental Change Material to Improve Student Learning Outcomes. Scientiae Educatia: Journal of Science Education, 6 (2), 197-213.

Bariah, S. (2013). Development of a Competency-Based High School Biology Learning Curriculum that is Educate, Competitive, Productive, and Moral. Cemerlang Journal, 1 (1).

Bintari, SH, \& Martuti, NKT (2012). Learning Virus Material Using Picture Cards at SMA Negeri 2 Wonosobo. Journal Of Biology Education, 1 (2).

Culture, LL (ND). Development of Integrating Society, Science, Environment, Technology, and Collaborative Mind Mapping (Issetcm2) Models to Empower Environmental Literacy.

Emda, A. (2017). Laboratory as a Learning Facility for Chemistry to Increase Knowledge and Scientific Work Skills. Lanthanide Journal, 5 (1), 83-92.

Erwanto, E. (2019). Implementation of the Integrated Islamic School Network (Jsit) Curriculum in the Formation of the Religious Character of Students of Smpit Khoiru Ummah Rejang Lebong. Al-Bahtsu: Journal of Islamic Education Research, 4 (1).

Falahudin, I. (2014). Use of Media in Learning. Widyaiswara Circle Journal, 1 (4), 104117.

Fulu, E., Miedema, S., Roselli, T., Mccook, S., Chan, KL, Haardörfer, R., Jewkes, R., Warner, X., Lang, J., \& Naved, RT
(2017 ). Pathways Between Childhood Trauma, Intimate Partner Violence, And Harsh Parenting: Findings From The Un Multi-Country Study On Men And Violence In Asia And The Pacific. The Lancet Global Health, 5 (5), E512 - E522.

Handayani, F. (2013). Relationship between Self Efficacy and Accelerated Student Achievement. Character: Journal of Psychological Research., 1 (2).

Hani'ah, STW, Suwandi, S., \& Saddhono, K. (2017). Building the Morality of the Young Generation with Education of Madurese Cultural Wisdom in Freedom. The 1st Education And Language International Conference Proceedings. Center For International Language Development Of Unissula.

Harahap, D. (2008). Analysis of the Relationship Between Student SelfEfficacy and Chemical Learning Outcomes. -.

Harahap, EK, Jambi, DSM, Thaha, DL Bi. US, \& Jambi, S. (2018). Utilization of Management Accreditation Results for Madrasahs with Achievement, Independent, Islamic and Global Competitiveness (Study at Man Insan Cendikia Serpong). Journal of Literacy, 1 (1), 28-28.

Hasanah, UN, Thahir, A., Komaruddin, K., \& Rahmahwaty, R. (2019). Murder Learning And Self Efficacy Models: Impact On Mathematical Reflective Thingking Ability. Journal For The Education Of Gifted Young Scientists, 7 (4), 1123-1135.

Hekmah, N., Wilujeng, I., \& Suryadarma, IGP (2019). Environmental Integrated Ipa Student Worksheet Web-Sheet To Improve Student Environmental Literacy. Journal of Ipa Educational Innovation, 5 (2), 129-138. 
Hidayati, N. (2016). Learning Outcomes and Critical Thinking Skills of Madrasah Tsanawiyah Students in Ipa Learning Through Scientific Work. Proceeding Biology Education Conference: Biology, Science, Environmental, And Learning, 13 (1), 118-127.

Husin, A. (2017). The Role of Population Education in Environmental Conservation. Demography Journal Of Sriwijaya (Dejos), 1 (1), 14-19.

Imelda, A. (2017). Implementation of Value Education in Islamic Religious Education. Al-Tadzkiyyah: Journal of Islamic Education, 8 (2), 227-247.

Indrawati, FA, \& Wardono, W. (2019). Effect of Self Efficacy on Mathematical Literacy Ability and Ability Formation 4c. Prisma, Proceedings of the National Mathematics Seminar, 2, 247-267.

Jatisunda, MG (2017). The Relationship between Junior High School Students' Self-Efficacy and Mathematical Problem Solving Ability. Journal of Theorems (The Original Research Of Mathematics), 1 (2).

Komariah, N., Yusup, PM, Saepudin, E., \& Rodiah, S. (2020). Dissemination of Environmental Care Information to the Community of Paledah Village, Pangandaran Regency. Dharmakarya, 9 (1), 34-37.

Kristiawan, M., Ahmad, S., Tobari, T., \& Suhono, S. (2017). Learning Design SMA Plus Negeri 2 Banyuasin Iii Based on Character in the Era of the Asean Economic Community. Journal of Iqra ': The Study of Educational Sciences, 2 (2), 403-432.

Kusmanto, H. (2014). Development of Interactive Mathematics Multimedia to Develop Mathematical Reasoning Ability (Mathematical Resasoning)
Elementary School Students. Al Ibtida: Mi Journal of Teacher Education, 1 (1).

Lailatussaadah, L., Fitriyawany, F., Erfiati, E., \& Mutia, S. (2020). Supporting and Inhibiting Factors in the Implementation of Online Learning (Online) Ppg in Position (Daljab) for Female Teachers in Aceh. Gender Equality: International Journal Of Child And Gender Studies, 6 (2), 41-50.

Nasution, R. (2016). Analysis of Environmental Literacy Ability for Class X High School Students at Samboja in Learning Biology. Proceeding Biology Education Conference: Biology, Science, Environmental, And Learning, 13 (1), 352-358.

Nuriadin, I., \& Perbowo, KS (2013). Correlation Analysis of Mathematical Creative Thinking Ability on Mathematics Learning Outcomes of Students at SMP Negeri 3 Lurangung Kuningan, West Java. Infinity Journal, 2 (1), 65-74.

Pane, A., \& Dasopang, MD (2017). Learning And Learning. Fitrah: Journal of Islamic Studies, 3 (2), 333-352.

Prasetyo, A. (2017). Connection Ability and Students' Mathematical Disposition in terms of Keirsey Personality Type in Mathematics Learning Model Eliciting Activities. Semarang State University.

Pudjiastuti, E. (2012). The Relationship between "Self Efficacy" and the Cheating Behavior of Psychology Students. Pulpit: Journal of Social and Development, 28 (1), 103-111.

Pujianti, N., Munandar, A., \& Surakusumah, W. (2018). Environmental Literacy In Agriculture And Coastal Areas. Journal Of Physics: Conference Series, 1013 (1). 
Biosfer, 11 (2) (2020) 159-168

Rani Rosdiana; Djohar Maknun; Evi Roviati

Qomara, E. (2015). The Effect of Education and Training Level on Employee Work Quality (Concept Approach). Public, 11 (2), 177-188.

Rahmi, N. (2017). The Relevance of the Curriculum and the Concrete Form of Arabic Learning Objectives. An Nabighoh: Journal of Arabic Language Education and Learning, 19 (1), 107126.

Rustaman, NY (2011). Education and Science Research in Developing Higher-Level Thinking Skills for Character Building. Proceeding Biology Education Conference: Biology, Science, Environmental, And Learning, 8 (1), $15-34$.

Shawmi, AN (2015). Life Skills Education in Learning Science at SD / Mi. Skilled: Journal of Education and Basic Learning, 2 (2), 240-252.

Siddiq, MN, Supriatno, B., \& Saefudin, S. (2020). The Effect of the Application of Problem Based Learning on Junior High School Students' Environmental Literacy on Environmental Pollution Material. Assimilation: Indonesian Journal Of Biology Education, 3 (1), $18-24$.

Sitompul, SS (2018). Testing Models for Physical Work Environment, Job Training And Employee Satisfaction Of Pt. Andalas Agro Lestari Logas. Costing: Journal Of Economic, Business And Accounting, 1 (2), 198208.

Sudarsana, IK (2016). Improving the Quality of Outside School Education in Human Resources Development Efforts. Journal of Quality Assurance, 1 (1), 114.
Sunaryo, Y. (2017). Measuring Student SelfEfficacy in Mathematics Learning at Mts N 2 Ciamis. Theorem: Mathematical Theory and Research, 1 (2), 39-44.

Supriyatin, S., Nurnawati, N., \& Heryanti, E. (2016). The Effect of the Application of Active, Joyful, and Effective Learning (Ajel) on Environmental Change Material on Students' Environmental Care Attitudes. Biosphere: Journal of Biological Education, 9 (2), 69-75.

Syarifuddin, A. (2011). Application of Learning Cooperative Learning Model and the factors that influence it. Ta'dib: Journal Of Islamic Education, 16 (01), 113-136.

Taff, MAM, Aziz, A., Haron, R., Rasyid, NM, \& Yasim, MM (2010). Residential Outdoor Education And Environmental Attitudes: An Examination In A Malaysian University. Journal Of Outdoor Recreation, Education, And Leadership, 2 (3), 198-216.

Trianingsih, R. (2017). Education in a Multicultural Cultural Process in Indonesia. Tarbiyatuna: Islamic Education Studies, 1 (1), 1-12.

Winataputra, US, Delfi, R., Pannen, P., \& Mustafa, D. (2014). The Nature of Learning and Learning. The Nature of Learning and Learning, 1-46. 